\title{
Indigenous Constitutionalism and Dispute Resolution Outside the Courts: An Invitation
}

Karen Drake

Osgoode Hall Law School of York University, kdrake@osgoode.yorku.ca

Source Publication:

Federal Law Review (September 2020)

Follow this and additional works at: https://digitalcommons.osgoode.yorku.ca/scholarly_works

Part of the Constitutional Law Commons, and the Indian and Aboriginal Law Commons

\section{Repository Citation}

Drake, Karen, "Indigenous Constitutionalism and Dispute Resolution Outside the Courts: An Invitation" (2020). Articles \& Book Chapters. 2812.

https://digitalcommons.osgoode.yorku.ca/scholarly_works/2812

This Article is brought to you for free and open access by the Faculty Scholarship at Osgoode Digital Commons. It has been accepted for inclusion in Articles \& Book Chapters by an authorized administrator of Osgoode Digital Commons. 


\title{
NOTE: This is a post-print version of a paper published in the Federal Law Review (2020), available here: \\ https://journals.sagepub.com/doi/full/10.1177/0067205X20955069
}

Indigenous Constitutionalism and Dispute Resolution Outside the Courts: An Invitation

Karen Drake*

\begin{abstract}
The Supreme Court of Canada's jurisprudence on constitutionally protected Aboriginal rights filters Indigenous laws through the lens of liberal constitutionalism, resulting in distortions of Indigenous law. To overcome this constitutional capture, this article advocates for an institution that facilitates dispute resolution between Canadian governments and Indigenous peoples grounded in Indigenous constitutionalism. To avoid a pan-Indigenous approach, this article focuses on Anishinaabe constitutionalism as one example of Indigenous constitutionalism. It highlights points of contrast between Anishinaabe constitutionalism's and liberalism's foundational norms and dispute resolution procedures. This article argues that a hybrid institution - combining features of both liberalism and Indigenous constitutionalism - would merely reproduce the constitutional capture of Aboriginal rights jurisprudence. It also illustrates how the procedures of talking circles - which are one means of giving effect to persuasive compliance - promote the voice of all involved. Finally, this paper argues that from the perspective of Anishinaabe constitutionalism, the non-binding nature of the processes offered by the new institution would be a strength, not a drawback.
\end{abstract}

\section{Introduction}

From one perspective, the story of constitutionally protected Indigenous rights in Canada has been one of progress. ${ }^{1}$ Section 35(1) of the Constitution Act, $1982^{2}$ recognizes and affirms the Aboriginal rights (including Aboriginal title) and treaty rights of the Aboriginal peoples of Canada. ${ }^{3} \mathrm{~A}$ series of court victories mean that, as Indigenous peoples, we have greater ability to engage in our cultural practices, ${ }^{4}$ to use our territories, ${ }^{5}$ and to exercise our rights protected by our treaties with the Crown. ${ }^{6}$ But from another

\footnotetext{
* Associate Professor, Osgoode Hall Law School at York University. I am very grateful to Andrew Christian Airhart and Gabrielle Pellerin for their excellent research assistance, and to those in attendance at the workshop for this special issue, to the anonymous reviewers, and to the journal's editors for their valuable suggestions and improvements. Any errors are my responsibility alone.

${ }^{1}$ Gordon Christie, Canadian Law and Indigenous Self-Determination (University of Toronto Press, 2019) 17, 130 ('Canadian Law').

2 Canada Act 1982 (UK) c 11, sch 3 ('Constitution Act 1982').

${ }^{3}$ I use the term 'Indigenous' to cohere with preferences for this term. I use the term 'Aboriginal' when referring to rights or peoples described in section 35.

${ }^{4} R v$ Powley [2003] 2 SCR 207.

5 Tsilhqot'in Nation v British Columbia [2014] 2 SCR 257 ('Tsilhqot'in Nation').

${ }^{6} R v$ Marshall [1999] 3 SCR 456.
} 
perspective, the story is one of disappointment and distortions. Despite the promise of 'reconciliation' ${ }^{7}$ the legal tests developed by the courts protect frozen rights instead of self-determination, ${ }^{8}$ and Aboriginal title is closer to a property interest in land than a power to exercise jurisdiction over territory. ${ }^{9}$

The first perspective is that of liberal constitutionalism; the second perspective is that of Indigenous constitutionalism. ${ }^{10} \mathrm{I}$ use the term 'constitutionalism' not in the narrow sense of a political system that places limits on governmental powers, but in the broader sense articulated by Aaron Mills, who uses this term to designate a framework for how a people constitutes itself as a political community.$^{11}$ Mills posits a tree model of legality, whose explanatory force applies equally to Indigenous and non-Indigenous legal orders. ${ }^{12}$ The roots of the tree represent a society's lifeworld or creation story, including its ontology and epistemology. ${ }^{13}$ Moving up, the trunk represents a society's constitutional order or its practice of governance that enables collective action, as just mentioned. ${ }^{14}$ Moving up further, the branches represent legal traditions in the sense of the processes by which the society generates, interprets, modifies, and destroys its laws. ${ }^{15}$ Finally, the leaves represent a society's laws. ${ }^{16}$ The key to this model is that each level empowers and constrains the one above, but does not definitively determine it. ${ }^{17}$ The roots of a birch tree can only produce a birch trunk but not, say, a pine trunk. And yet, birch trunks vary greatly. ${ }^{18}$ The tree model of legality cautions against attempts to filter Indigenous legal orders through the lens of liberal constitutionalism. ${ }^{19}$ Birch leaves can't be removed from a birch tree and pasted onto a pine tree; they won't grow. Likewise, attempts to implement Indigenous laws within the political and legal architecture of a liberal state result in incoherence and structural violence to Indigenous law, which Mills describes as constitutional capture ${ }^{20}$ and which Gordon Christie describes as a liberal or colonial snare. ${ }^{21}$ As Christie demonstrates, the Supreme Court of Canada's section 35(1) jurisprudence is one immense liberal snare. ${ }^{22}$ From this perspective, the Court's section 35(1) jurisprudence is not the rejection of colonialism, but rather the perfection of it. ${ }^{23}$

7 R v Van der Peet [1996] 2 SCR 507 [31] ('Van der Peet').

8 Ibid; $R$ v Pamajewon [1996] 2 SCR 821.

9 Tsilhqot'in Nation (n 5) [149]-[151]; Gordon Christie, 'Who Makes Decisions over Aboriginal Title Lands?' (2015) 48(3) University of British Columbia Law Review 743. See especially 754.

10 Christie, Canadian Law (n 1) 130.

11 Aaron Mills, 'The Lifeworlds of Law: On Revitalizing Indigenous Legal Orders Today' (2016) 61(4) McGill Law Journal 847, 855 n 14 ('Lifeworlds').

12 Aaron James (Waabishki Ma'iingan) Mills, Miinigowiziwin: All That Has Been Given for Living Well Together: One Vision of Anishinaabe Constitutionalism (PhD Dissertation, Faculty of Law, University of Victoria, 22 July 2019) 39 ('Miinigowiziwin').

${ }_{13}$ Mills, 'Lifeworlds' (n 11) 862; Mills, Miinigowiziwin (n 12) 41-3.

14 Mills, Miinigowiziwin (n 12) 41-3.

15 Ibid 45.

16 Ibid 46.

17 Ibid 40-1.

18 Ibid 41.

19 Ibid 8 59-62, n 45. See also Gordon Christie, 'Culture, Self-Determination and Colonialism: Issues Around the Revitalization of Indigenous Legal Traditions' (2007) 6(1) Indigenous Law Journal 13 ('Culture'); Sara J Mainville, 'Treaty Councils and Mutual Reconciliation under Section 35' (2007) 6(1) Indigenous Law Journal 141, 173 , 177 ('Treaty Councils') (advocating that Treaty Three should be understood through the lens of the sacred laws of the Anishinaabeg, and not through the lens of Canadian institutions).

${ }^{20}$ Mills, Miinigowiziwin (n 12) 8, 28, 36.

${ }^{21}$ Christie, 'Culture' (n 19) 14-18, cited in Mills, Miinigowiziwin (n 12) 36.

22 Christie, 'Culture' (n 19) 16-17; Christie, Canadian Law (n 1) chs 7-8.

${ }^{23}$ Gordon Christie, 'Indigenous Legal Orders, Canadian Law and UNDRIP' in UNDRIP Implementation: Braiding International, Domestic and Indigenous Laws (Centre for International Governance Innovation, 2017) 48, 49. 
The tree model is not an instance of legal pluralism. While legal pluralism would be an improvement over the current section 35 jurisprudence, it still perpetuates constitutional capture. ${ }^{24}$ Legal pluralism typically gives effect to Indigenous legal orders only at the level of the leaves (laws) or at best, at the levels of the leaves and the branches (legal processes). ${ }^{25}$ To avoid constitutional capture, we need to give effect to Indigenous legal orders at all four levels. If we were to accomplish that, we would no longer be dealing with more than one legal order operating under the aegis of a single constitution; in other words, we would no longer be dealing with legal pluralism. Instead, we would be dealing with separate nations in a relationship with each other.

I propose that disputes about the operation of Indigenous laws could be addressed through a forum that facilitates dispute resolution grounded in Indigenous constitutionalism. The forum would provide an alternative to section 35 litigation and replace both the Comprehensive Claims process ${ }^{26}$ and the federal government's Inherent Rights Policy (and the accompanying process for negotiating self-government agreements). ${ }^{27}$ It could also serve as an alternative to the Specific Claims Tribunal. ${ }^{28}$ These existing dispute resolution mechanisms employ concepts and processes 'drawn solely from the dominant settler legal system' 29 and thus exhibit the same constitutional capture produced by the section 35 jurisprudence. ${ }^{30}$ The benefits of the new forum would include avoiding not only constitutional capture but also the drawbacks of litigation. The inefficiencies and tremendous costs (in terms of money, time, resources, and uncertainty) of litigation of Aboriginal rights are well known. ${ }^{31}$ Although the Supreme Court of Canada has nudged the parties toward negotiation, ${ }^{32}$ the Crown still has 45,000 legal claims against it by First Nations. ${ }^{33}$ Moreover, a new dispute resolution process grounded in Indigenous procedures could fulfill article 27 of the United Nations Declaration on the Rights of Indigenous Peoples, which

24 Mills, Miinigowiziwin (n 122) 36.

25 Ibid 35-6.

26 'Comprehensive Claims', Government of Canada (Web Page, 13 July 2015) <www.rcaanccirnac.gc.ca/eng/1100100030577/1551196153650>.

27 'The Government of Canada's Approach to Implementation of the Inherent Right and the Negotiation of Aboriginal Self-Government', Government of Canada (Web Page, 15 September 2010) <www.rcaanccirnac.gc.ca/eng/1100100031843/1539869205136>.

28 'Specific Claims Tribunal Canada', Specific Claims Tribunal Canada (Web Page, 12 May 2020) <www.scttrp.ca/hom/index_e.htm>. For a discussion of the development of Canada's Specific Claims and Comprehensive Claims policies, see Michael Coyle, 'ADR Processes and Indigenous Rights: A Comparative Analysis of Australia, Canada and New Zealand' in Benjamin J Richardson, Shin Imai and Kent McNeil (eds), Indigenous People and the Law: Comparative and Critical Perspectives (Hart Publishing, 2009) 371, 383-5 ('ADR Processes').

${ }^{29}$ ADR Processes (n 28) 398. See also Michael Coyle, 'Transcending Colonialism? Power and the Resolution of Indigenous Treaty Claims in Canada and New Zealand' (2011) 24(4) New Zealand Universities Law Review 596, 619 ('Transcending Colonialism?') (explaining that 'both the Specific Claims Policy and the enabling legislation of the Specific Claims Tribunal fail almost entirely to incorporate indigenous values as relevant criteria in resolving treaty claims').

30 An exception may be the Office of the Treaty Commissioner in Saskatchewan which collected and documented elders' understandings of the treaties covering what is now known as Saskatchewan: Harold Cardinal and Walter Hildebrandt, Treaty Elders of Saskatchewan: Our Dream Is That Our Peoples Will One Day Be Clearly Recognized as Nations (University of Calgary Press, 2000).

${ }^{31}$ Douglas R Eyford, A New Direction: Advancing Aboriginal and Treaty Rights (Report by the Canadian Ministerial Special Representative on Renewing the Comprehensive Land Claims Policy, 2015) 29; Musqueam Indian Band $v$ British Columbia (Minister of Sustainable Resource Management) [2005] BCCA 128, [54]-[55]; @benralstonyxe (Benjamin Ralston) (Twitter, 28 February 2020) <https://twitter.com/benralstonyxe/status/1233576426961391616>.

32 Delgamuukw v British Columbia [1997] 3 SCR 1010, [186]; Tsilhqot'in Nation (n 5) [17].

${ }^{33}$ Hayden King and Shiri Pasternak, Canada's Emerging Indigenous Rights Framework: A Critical Analysis (Yellowhead Institute, 5 June 2018) 19. 
requires states in conjunction with Indigenous peoples to implement a process for recognizing Indigenous peoples' rights that gives due recognition to Indigenous peoples' laws. ${ }^{34}$

Some impetus for a new dispute resolution process already exists. The federal Liberal government's proposed 'Recognition and Implementation of Indigenous Rights Framework' - announced during the Liberal government's previous mandate-would have introduced new legislation and policies intended to uphold section 35 rights and implement the United Nations Declaration on the Rights of Indigenous Peoples. ${ }^{35}$ The Framework also would have established a new dispute resolution institution providing a non-binding forum for resolving Aboriginal and treaty rights disputes using 'Indigenous knowledge; legal traditions; and, customary laws'. ${ }^{36}$

The proposed Framework was widely criticized for its narrow vision of Indigenous self-government. ${ }^{37}$ References to the Framework in government communications eventually ceased, but the federal government continues to develop individual statutes covering topics contemplated by the Framework. ${ }^{38}$ The mandate letter to the Minister of Crown-Indigenous Relations issued after the 2019 federal election makes no mention of the Framework, but emphasizes many initiatives which were components of the Framework. ${ }^{39}$ While the letter is silent on the proposed dispute resolution institution, it does direct the Minister to work with Indigenous peoples in redesigning the Specific Claims process, the Comprehensive Claims process, and the Inherent Rights Policy. ${ }^{40}$ If the redesign results in mere tinkering without jettisoning the liberal foundations of these processes, it will be a wasted opportunity. A new dispute resolution process using Indigenous procedures grounded in Indigenous lifeworlds and constitutional orders would help Indigenous peoples escape from the liberal snare.

To avoid the pitfalls of a pan-Indigenous approach, this article focuses on Anishinaabe constitutionalism as one example of Indigenous constitutionalism. My discussion primarily draws on the work of Aaron Mills, and is supplemented by the works of others including John Borrows, Aimée Craft, Sara Mainville, Leanne Simpson, and Heidi Stark. But of course, the proposed forum would need to provide processes that instantiate the constitutional orders and dispute resolution procedures of each Indigenous nation across Canada.

The next section provides a brief summary of the roots, trunk, and branches of an Anishinaabe society (as articulated by Mills), which are contrasted with those of liberalism. At the level of the trunk, I discuss the logic of Anishinaabe constitutionalism - mutual aid. At the level of the branches, I focus on the role of persuasive compliance within Anishinaabe dispute resolution processes, which is contrasted with the coercive authority exercised by the liberal state. Section Three describes the functions of the proposed forum and argues that a hybrid forum - combining features of both liberal and Indigenous

34 United Nations Declaration on the Rights of Indigenous Peoples, GA Res 61/295, UN Doc A/RES/61/295 (2 October 2007, adopted 13 September 2007) art 27.

35 'Overview of a Recognition and Implementation of Indigenous Rights Framework', Government of Canada (Web Page, 10 September 2018) <www.rcaanc-cirnac.gc.ca/eng/1536350959665/1539959903708>.

36 Ibid.

${ }^{37}$ King and Pasternak (n 33) 4; Joyce Green, 'It's time for a Recognition of Wrongs framework', Policy Options (online, 26 September 2019) < policyoptions.irpp.org/magazines/september-2019/its-time-for-a-recognition-of-wrongsframework/>; Jorge Barrera, 'Battle brewing over Indigenous rights recognition framework', CBC News (online, 11 September 2018) <www.cbc.ca/news/indigenous/indigenous-rights-framework-bennett-1.4819510>.

38 'Indigenous rights framework far from dead as Trudeau government rolls it out in pieces', APTN News (online, 1 February 2019) <aptnnews.ca/2019/02/01/indigenous-rights-framework-far-from-dead-as-trudeau-governmentrolls-it-out-in-pieces/>.

${ }_{39}$ Minister of Crown-Indigenous Relations Mandate Letter from Justin Trudeau to Carolyn Bennett, 13 December 2019 <https:/ / pm.gc.ca/en/mandate-letters/2019/12/13/minister-crown-indigenous-relations-mandate-letter>. 40 Ibid. 
constitutionalisms - would merely reproduce the liberal snare. Section Three also illustrates how the procedures of talking circles - which are one means of giving effect to persuasive compliance - promote the voice of all involved. Finally, I argue that from the perspective of Anishinaabe constitutionalism, the non-binding nature of the processes offered by the new forum would be a strength, not a drawback.

\section{Anishinaabe Constitutionalism and Liberal Constitutionalism}

\section{A Overview}

This section briefly juxtaposes Aaron Mills' account of Anishinaabe constitutionalism with some features of liberalism. The tree model of legality reveals the incommensurability between Anishinaabe constitutionalism and liberal constitutionalism takes hold at the level of the roots and flows from there to the other three levels. In this section, I identify various pressure points of incommensurability at the first three levels. Given the many different permutations of liberalism, not all of these pressure points exist within every instantiation of liberal constitutionalism. ${ }^{41}$ In other words, I do not claim all permutations of liberalism exhibit all of the features discussed in this section. That being said, in my view, at least one of these pressure points - discussed below in the context of the roots - is unavoidable. As a result, some measure of incommensurability will always obtain between Anishinaabe constitutionalism and liberal constitutionalism. No amount of tweaking of liberalism will eliminate this incommensurability.

Thus, the discussions in this section are not meant to be summaries - much less comprehensive summaries - of either Anishinaabe constitutionalism ${ }^{42}$ or liberalism. Not only is this an impossible task in a paper of this length, it is unnecessary. I am engaging in neither a critique of liberalism nor a defence of Anishinaabe constitutionalism. Anishinaabeg should be able to implement their laws in accordance with Anishinaabe constitutionalism not because of the superiority of Anishinaabe constitutionalism, but because if self-determination means anything, it means being free from constitutional capture.

\section{B The Roots: Lifeworlds}

Beginning with the roots of an Anishinaabe society, Mills explains the concept of miinigowiziwin includes all the gifts of creation - land, language, teachings, among others - given to us by a higher power, Creator, to live. ${ }^{43}$ Creation is imbued with an inherent normative order, according to which we have a responsibility to identify, develop, and use our unique gifts, including both our sacred gifts and our ordinary gifts of knowledge, skill, labour, material goods, and so on, just as the earth gives its gifts to us. ${ }^{44}$ This inherent normative order is also known as sacred law, the great law, Creator's law, or the original instructions. ${ }^{45}$ By complying with these original instructions, we live in harmony with creation. ${ }^{46}$

\footnotetext{
41 This conclusion might also follow from the different expressions of Anishinaabe constitutionalism, but my knowledge of Anishinaabe constitutionalism is not sufficient to make this claim.

42 For more comprehensive accounts of Anishinaabe constitutionalism, see Mills, Miinigowiziwin (n 12); Mills, 'Lifeworlds' (n 11). See also Aaron Mills, Karen Drake \& Tanya Muthusamipillai, 'An Anishinaabe Constitutional Order' in Patrick Smith (ed), Reconciliation in Canadian Courts: A Guide for Judges to Aboriginal and Indigenous Law, Context and Practice (National Judicial Institute, 2017) 260.

${ }_{43}$ Mills, Miinigowiziwin (n 12) 68-9. For further discussion of miinigoziwin, see Mainville (n 19) 177.

44 Mills, Miinigowiziwin (n 12) 69-72, 74.

45 Ibid 69-70; Aimée Craft, 'Navigating Our Ongoing Sacred Legal Relationship with Nibi (Water)' in UNDRIP Implementation: More Reflections on the Braiding of International, Domestic and Indigenous Laws (Centre for International Governance Innovation, 2018) 53, 59.

${ }_{46}$ Mills, Miinigowiziwin (n 12) 75.
} 
None of us has all of the gifts (material, spiritual, emotional, intellectual) needed to be self-sustaining. ${ }^{47}$ And so we are radically interdependent with other persons. ${ }^{48}$ Mills uses the qualifier 'radical' to indicate that 'interdependence' here is not a means of conceptualizing individual autonomy. ${ }^{49}$ Nor is it a privileging of the collective over the individual; in fact, a dichotomy between the individual and the collective does not resonate within Anishinaabe constitutionalism. ${ }^{50}$ Persons include not only humans but all aspects of the natural world such as plants, animals, spirits, rocks, and rivers, among others. ${ }^{51}$ They are agents who possess intelligence and volition. ${ }^{52}$ Our gift-giving and receiving responsibilities, and hence our radical interdependence, extend to these non-human persons.

In contrast, the foundation of liberalism is not a recognition of what is unique to each of us (our unique gifts) but rather a claim about what is common to each: the inherent dignity of the human person. 53 Instead of having a responsibility to give the gifts we have been given in accordance with creation's original instructions, each individual human is entitled to define, pursue, and revise our own conception of the good life. ${ }^{54}$ In other words, we are each entitled to delineate our own individual 'original instructions'. To protect our ability to do so, liberalism upholds the freedom of the individual (negative and/or positive freedom) and the equality of the individual (formal and/or substantive equality). ${ }^{55}$ Our society's laws do not inhere in the natural world, but rather find their source in human institutions such as the legislative and judicial branches of government. ${ }^{66}$ Elements of the natural world (animals, plants, earth, water), in most instantiations of liberalism, are not legal persons. ${ }^{57}$

I understand the entitlement of each individual human to define, pursue, and revise our own conception of the good life, to be a foundational tenet of liberalism. ${ }^{58}$ This is the heart of the incommensurability. This tenet is fundamentally at odds with the original instructions of Anishinaabe constitutionalism according to which we each have a responsibility to identify, develop, and give our gifts. The notion that if we just articulate a progressive enough version of liberalism, we can overcome the incommensurability, might

\footnotetext{
47 Ibid 82.

48 Ibid 78-9.

$49 \mathrm{Ibid} 79$. For a relational account of individual autonomy that remains committed to a liberal view of the relationship between the individual and the state, see Jennifer Nedelsky, Law's Relations: A Relational Theory of Self, Autonomy, and Law (Oxford University Press, 2011).

50 Mills, Miinigowiziwin (n 12) 175.

51 Ibid 80; Craft (n 45) 57-8.

52 Mills, Miinigowiziwin (n 12) 80.

53 See Van der Peet (n 7) [18]; Mills, Miinigowiziwin (n 12) 84.

54 Will Kymlicka, Multicultural Citizenship: A Liberal Theory of Minority Rights (Oxford University Press, 1995$) 80$.

55 For a discussion of negative and positive freedom and formal and substantive equality, see Christie, Canadian Law (n 1) 278-80, 281-2.

56 This is a feature of positivism rather than liberalism. For a discussion of the liberal positivism underlying the Supreme Court of Canada's section 35(1) jurisprudence, see Christie, Canadian Law (n 1) chs 7-8.

57 Ibid 353. Exceptions have emerged in recent years, such as New Zealand's Te Urewera Act 2014 (NZ), which establishes that Te Urewera ceases to be a national park and is a legal entity with the rights, duties and liabilities of a legal person: see Jacinta Ruru, 'Tūhoe-Crown settlement-Te Urewera Act 2014' (2014) (October) Māori Law Review <http:/ / maorilawreview.co.nz/2014/10/tuhoe-crown-settlement-tuhoe-claims-settlement-act-2014-te-urewerareport-of-the-waitangi-tribunal/ $>$. This development, however, is still subject to constitutional capture, as the legislation is still firmly ensconced within the rights discourse of liberalism, discussed in the next sub-section. For a list of similar developments: see Craft (n 45) 55. Craft highlights the constitutional capture to which these developments are subject when she explains that by using non-Indigenous, state-derived legal mechanisms to recognize our sacred relationships with water and land, we risk losing the spirit of the relationship: at 55, 56. 58 Kymlicka (n 54) 80.
} 
find some success with other pressure points. ${ }^{59}$ But this one, at least, is inescapable. Some of its manifestations are discussed in section three below.

\section{The Trunk: Constitutional Orders}

At the level of the trunk, Mills identifies the logic informing an Anishinaabe constitutional order: wiidookodaadiwin or mutual aid. ${ }^{60}$ Giving a gift generates gratitude, which generates reciprocity, which generates the giving of further gifts, and so on. ${ }^{61} \mathrm{In}$ other words, the logic of mutual aid is cyclical. ${ }^{62} \mathrm{We}$ each have a responsibility to identify, develop, and use our own gifts to meet the needs of others, which entails responsibilities to identify the needs of others as well as their gifts, and to communicate our own needs. ${ }^{63}$ This raises questions about the limits of our responsibilities: Whose needs should we prioritize? How much of our gifts should we give to others? The answer is our responsibilities are bounded by our kinship relationships. ${ }^{64}$ Different kinship relationships - such as the relationship between father and child or the relationship between siblings - structure our mutual aid responsibilities differently. ${ }^{65}$ Kinship relationships can be extended, for example, to create a treaty relationship which typically encompasses the responsibilities of a sibling relationship but can also map onto a parent-child relationship. ${ }^{66}$

Reciprocity within the mutual aid logic is not necessarily direct reciprocity. ${ }^{67} \mathrm{~A}$ gift does not require a direct counter-gift. ${ }^{68} \mathrm{~A}$ can give to $\mathrm{B}$ who can give to $\mathrm{C}$ or $\mathrm{D}$ or $\mathrm{E}$, who can give to $\mathrm{Z}$ and so on, such that A's needs will eventually be met in a healthy mutual aid community. ${ }^{69}$ Thus, being called on to give a gift is not necessarily a burden..$^{70}$ In fact having a responsibility (to fulfill a need) is itself a gift. ${ }^{71}$ To have responsibilities is to be in relationships, and to be in relationships is to have others' gifts shared with you. ${ }^{72}$ Thus the logic of mutual aid entails a context of abundance, not scarcity. ${ }^{73}$

Anishinaabe constitutionalism is oriented toward harmony. ${ }^{74}$ Harmony does not necessarily mean an absence of conflict. ${ }^{75}$ Rather, harmony describes the operation of mutual aid; it is the connection between community members who give and accept gifts in accordance with their responsibilities within their relationships. ${ }^{76}$

In contrast, liberalism's normative architecture is structured not in terms of gifts and needs, but rights and duties. The logic underpinning rights and duties is not cyclical, but binary; if someone has a right, then some entity (some other person(s) and/or the state) has a corresponding duty not to violate that

\footnotetext{
59 One might argue the developments recognizing rights of aspects of the natural world, such as those discussed above at $\mathrm{n} 57$, constitute an example of the weakening of one pressure point.

60 Mills, Miinigowiziwin (n 12) 96-7, 98.

61 Ibid 100-1, 102.

62 Ibid 98.

63 Ibid 88.

64 Ibid 114.

65 Ibid 115-16.

66 Ibid 117, 119.

67 Ibid 107.

68 Ibid.

${ }^{69}$ Ibid 113.

70 Ibid 106.

71 Ibid 154.

72 Ibid.

73 Ibid 101-2.

74 Ibid 125-6.

75 Ibid 126.

76 Ibid.
} 
right.77 "Duty" is sometimes used interchangeably with "obligation" or "responsibility". I suspect the appearance of the term "responsibility" here is what leads some to assume a rights discourse can be unproblematically imported into Anishinaabe constitutionalism. But as Aimée Craft explains, responsibilities within Anishinaabe constitutionalism are not one side of a binary with rights on the other. ${ }^{78}$ Rather, responsibilities perform the function of correlating gifts and needs within relationships. Returning to liberalism, rights are held by, and duties owed to, not only those with whom we are in a relationship but also strangers. Finally, the end to which liberalism is oriented is not harmony, but justice, according to which rights are upheld and duties fulfilled. Justice does not generate a context of abundance as mutual aid does. To require us to give up some of our material resources, labour, etc., without our consent is to impinge on our negative freedom. On some versions of liberalism, this imposition is warranted to support the positive freedom of others, but it is nonetheless acknowledged as an imposition, albeit one that is justified. Within this zero-sum context, rational actors are entitled to pursue their self-interest within the bounds of law. ${ }^{79}$

\section{The Branches: Dispute Resolution Processes}

Unlike liberal societies where law is imposed by the state's legitimate exercise of force, within an Anishinaabe constitutional society as described by Mills, law's force comes from persuasive compliance, not coercion. ${ }^{80}$ Persuasive compliance refers to the practice of community members being persuaded to accept a given legal norm and choosing to follow it. ${ }^{81}$ In other words, the force of law is not external (imposed by an executive branch of government such as police, a sheriff's office, or other mechanism for enforcing legislation and court judgments), but rather internal: '[i]t is as though everybody is a "cop" and nobody is a "cop"'.82 This conception of law's force flows directly from the logic of mutual aid. Recall that the concept of rights plays no role within this account of Anishinaabe constitutionalism. Rights delineate generalisable rules, and as such, provide the certainty and determinacy needed by an external force to impose laws consistently on others. ${ }^{83}$ Gifts and needs are neither rights nor expressed as rules. ${ }^{84}$ Instead, each and every community member practices the law by exercising their judgment regarding their responsibilities within their relationships in the light of their and others' gifts and needs. ${ }^{85}$ As Mills explains: '[n]othing about the need to ... "live in harmony with the world" ... points toward particular actions or decisions. One is always forming judgments, "being" the law'. ${ }^{86}$ Far from subsuming an individual's agency to the will of the collective - which is a common (mis)characterisation of Indigenous societies - this practice of being the law 'requires a constant exercise of individual agency' ${ }^{87}$ The Anishinaabemowin word often translated as 'law' - inaakonigewin - reflects this view. Mills explains that 'inaakonigewin' does not refer to law in the sense of universalizable rules. It refers to a form of judgment in

77 See John Borrows, Law's Indigenous Ethics (University of Toronto Press, 2019) 129.

78 Craft (n 45) 56.

${ }^{79}$ Mills, Miinigowiziwin (n 12) 101.

80 Ibid 161, 163.

81 Ibid 164-5.

82 Little Bear, 'Jagged Worldviews Colliding' in Marie Battiste (ed), Reclaiming Indigenous Voice and Vision (UBC Press, 2000) 77, 84, cited by Mills, Miinigowiziwin (n 12) 161. See also Phil Lancaster, 'Omaminomowayak: Anishinaabe Justice in Muskrat Dam First Nation' (1994) 14 Windsor Yearbook of Access to Justice 331, 340.

83 Mills, Miinigowiziwin (n 12) 65-6.

84 Ibid 136, 138-9.

85 Ibid 135, 166

86 Ibid 140.

87 Ibid 135, 140. 
the sense of an exercise of discernment. ${ }^{88}$ Thus, inaakonigewin is a process of careful decision-making and is deeply deliberative. ${ }^{89}$

One might wonder what prevents members of a society governed by Anishinaabe constitutionalism from refusing to participate in persuasive compliance and exercising their judgment to make decisions that merely serve their self-interest. Mills describes three kinds of persuasive compliance, the first of which follows most directly from the logic of mutual aid: positive reinforcement. ${ }^{90} \mathrm{In}$ a radically interdependent society where one's freedom depends on the flourishing of one's community members, 'it only makes sense that I should be more motivated by the prospect of sustaining good relationships than I am by the prospect of constrained or diminished individual choice' ${ }^{91}$ Sara Mainville explains this dependency does not have a negative connotation; it is a sign of kinship and strength. ${ }^{92} \mathrm{~A}$ dichotomy between self-interest and altruism resonates within liberalism, but not within Anishinaabe constitutionalism. Instead, it is more accurate to say we all thrive together or we all suffer together. ${ }^{93}$ In those rare circumstances when persuasive compliance is not effective, the community as a whole is entitled to exercise coercive force as long as it complies with accepted procedures for ensuring the legitimacy of the community's decision. ${ }^{94}$

Of the five sources of Indigenous law identified by John Borrows, the one that best coheres with mutual aid and persuasive compliance as a form of dispute resolution is deliberative law, which refers to 'processes of persuasion, deliberation, council, and discussion'. ${ }^{95}$ It 'can occur in formal and informal meetings and gatherings' through highly structured or ad hoc means. ${ }^{96}$ The next section discusses how the proposed new forum can facilitate the operation of persuasive compliance through deliberative law.

\section{Deliberative Law and an Indigenous Dispute Resolution Forum}

\section{A Functions of an Indigenous Dispute Resolution Forum}

The two primary functions of the new forum would be - in the following order - first, to provide training and capacity-building to Canadian government representatives about Indigenous constitutional orders, and second, to provide facilitators who can guide the parties in using Indigenous dispute resolution procedures such as talking circles. As illustrated in the preceding section, a grounding in an Anishinaabe lifeworld and constitutional logic (the roots and trunk) is a necessary precursor to the use of Anishinaabe dispute resolution procedures (the branches). ${ }^{97}$ This requires more than mere intercultural competency training, which typically focuses on differing substantive norms, as opposed to differing lifeworlds and constitutional logics. For Anishinaabe procedures to function as such, those engaged in the process must

\footnotetext{
88 Ibid 135, 142.

89 Ibid 144.

90 The other two are negative social force and negative manidoo/medicine force: Mills, Miinigowiziwin (n 12) 135.

91 Ibid 175.

92 Mainville (n 19) 157.

93 Aaron Mills, 'What is a Treaty? On Contract and Mutual Aid' in John Borrows and Michael Coyle, The Right

Relationship: Reimagining the Implementation of Historical Treaties (University of Toronto Press, 2017) 208, 209-10, 214

('Treaty').

94 See John Borrows, Canada's Indigenous Constitution (University of Toronto Press, 2010) 80 ('Indigenous Constitution') 81-4; Lancaster (n 82) 342-3.

95 Borrows, Indigenous Constitution (n 94) 35. The other sources include sacred law, natural law, positivistic law, and customary law: ch 2.

96 Ibid 36. For an account of the dispute resolution procedures of Muskrat Dam First Nation which reflect mutual aid and persuasive compliance remarkably clearly, see Lancaster (n 82) 337-43.

${ }^{97}$ For a similar point regarding a Navajo legal order, see Chief Justice Robert Yazzie, 'Navajo Peacemaking and Intercultural Dispute Resolution' in Catherine Bell and David Kahane (eds), Intercultural Dispute Resolution in Aboriginal Contexts (UBC Press, 2004) 107, 110.
} 
be capable of implementing the logic of mutual aid. Otherwise, the significance of the procedures becomes distorted by the competing logic and the result is constitutional capture.

The need for capacity-building among Canadian government representatives is demonstrated by both Indigenous people's feedback ${ }^{98}$ and government representatives' own actions. ${ }^{99}$ My proposal counters the deficiency model regarding Indigenous peoples, which is sometimes applied even by those seeking to improve outcomes for Indigenous peoples. The deficiency model assumes Indigenous peoples encounter problems because of a deficit or lack on their part, such as a lack of capacity, education, skills, knowledge, or funding. ${ }^{100}$ For example, Indigenous communities and individuals are often the target market for training programs in negotiation and dispute resolution skills. ${ }^{101} \mathrm{I}$ know of no similar programs aimed at teaching Canadian government representatives how to operate in accordance with the logic of mutual aid in order to engage in persuasive compliance (as opposed to the substantive norms taught by cultural competency programs). The party who suffers from a deficiency in this relationship is the Canadian state, and this deficiency is responsible for the liberal snare.

The Treaty of Niagara of 1764 can serve as a template for a mutual aid relationship that uses persuasive compliance as a means of dispute resolution. ${ }^{102}$ As Heidi Stark explains, from an Anishinaabe perspective, a treaty is not analogous to a contract, where the rights and responsibilities of each party can be established conclusively at the outset. ${ }^{103}$ According to Leanne Simpson, this is reflected in an Anishinaabemowin term for treaty: Chi-debahk-(in)-Nee-Gay-Win, which refers to 'an agreement that is an ongoing reciprocal and dynamic relationship to be nurtured, maintained, and respected' ${ }^{104}$ In other words, a treaty relationship is a mutual aid relationship on a larger scale. Over time, gifts change and needs change. The parties to the treaty must come together periodically to reassess their gifts, needs, and responsibilities. They do this by regularly meeting together in a council, by deliberating about any issues that arose between them since their last meeting, and by addressing those issues to restore harmony using persuasive compliance. ${ }^{105}$ This is the process of renewing the treaty. ${ }^{106}$ This practice should be familiar to the Canadian government; British/colonial governments engaged in the practice of regularly renewing the Treaty of Niagara of 1764 with Ansihinaabeg for almost one hundred years, until 1854. ${ }^{107}$ Mainville demonstrates that this type of regular treaty council is a treaty right pursuant to Treaty

98 See Government of Canada, 'What we heard so far on the recognition and implementation of Indigenous rights', (Web Page, 13 July 2018) <www.rcaanc cirnac.gc.ca/eng/1531408653300/1539960280640> (reporting feedback from Indigenous people on the lack of understanding and education among government employees and representatives). 99 See Kerry Wilkins, 'Reasoning with the Elephant: The Crown, Its Counsel and Aboriginal Law in Canada' (2016) 13(1) Indigenous Law Journal 27, 67-70.

100 Deborah McGregor, 'Truth Be Told: Redefining Relationships through Indigenous Research' in Karen Drake and Brenda L Gunn, Renewing Relationships: Indigenous Peoples and Canada (Wiyasiwewin Mikiwahp Native Law Centre, 2019) 9, 14-17, 21.

101 Rebecca Ratcliffe and Catherine Bell, ‘Western ADR Processes and Indigenous Dispute Resolution' (Draft Paper) 14-15 <www.coemrp.ca/wp-content/uploads/2015/12/Final-Western-DR-Systems-.pdf>.

102 See Mills, 'Treaty' (n 93) 238.

103 Ibid 225; Heidi Kiiwetinepinesiik Stark, 'Respect, Responsibility, and Renewal: The Foundations of Anishinaabe Treaty Making with the United States and Canada' (2010) 34(2) American Indian Culture and Research Journal 145, 149. 104 Leanne Simpson, 'Looking after Gdoo-naaganinaa: Precolonial Nishnaabeg Diplomatic and Treaty Relationships' (2008) 23(2) Wicazo Sa Review 29, 35.

105 See The Centre for Indigenous Studies, 'Alan Corbiere: 250th Anniversary of the Treaty of Niagara' (YouTube, 15 December 2014) <www.youtube.com/watch?v=aGMIyGtyT7E>.

106 Stark (n 103) 153, 155, 156.

107 See The Centre for Indigenous Studies (n 105); John Borrows, 'Wampum at Niagara: The Royal Proclamation, Canadian Legal History, and Self-Government' in Michael Asch (ed), Aboriginal and Treaty Rights in Canada: Essays on Law, Equality, and Respect for Difference (UBC Press, 1997) 155, 165-8. 
Three. ${ }^{108}$ The forum I propose would help Canadian government representatives acquire the understanding needed to participate effectively in these treaty councils.

\section{B Rejecting a Hybrid Procedure}

The forum I propose would be grounded entirely in the lifeworld (roots), constitutional order (trunk), and procedures (branches) of an Indigenous people to ensure the resulting decisions (leaves) are not distorted by constitutional capture. In other words, this forum would not be a hybrid mechanism which combines elements of both Indigenous and non-Indigenous dispute resolution procedures. NonIndigenous dispute resolution procedures are not value neutral. As Neil Brooks explains, the adversarial system embodies liberal norms, including the primacy of individual autonomy and self-interest, insofar as (i) litigants have the right to choose how to frame their case and the proofs they present, and (ii) the system is not self-activating but rather depends on litigants advancing their own interests. ${ }^{109}$ As David Kahane observes, 'the idea of a neutral adjudicator presupposes some authoritative system of law and rule under which parties to a dispute are jointly situated ... [but this] is precisely what is at issue'.110 Indigenous peoples dispute the legitimacy of the Canadian state's assertion of sovereignty, and hence the operation of its legal system.

A critic might argue alternative dispute resolution (ADR) procedures such as mediation and negotiation (but not arbitration which mirrors an adversarial process) avoid constitutional capture insofar as they overlap with Indigenous dispute resolution procedures. However, despite some superficial similarities at the level of the branches, non-Indigenous ADR and Indigenous dispute resolution procedures are informed by fundamentally different roots and trunks. ${ }^{111}$ Even interest-based mediation and negotiation presuppose an ontology of individual interest-bearers navigating divergent interests. ${ }^{112}$ The operation of persuasive compliance within deliberative law involves not a calculated trade-off of some individual interests to secure others, but rather collective deliberation grounded in our shared radical interdependence. ${ }^{113}$ Of course, Indigenous nations may choose to create and participate in systems that combine features of disparate constitutional orders, as they are entitled to do as self-determining nations. ${ }^{114}$ For example, New Zealand's Waitangi Tribunal has been described as a 'bicultural' body. ${ }^{115}$ Its procedures are in essence inquisitorial, including court-like hearings where parties are represented

\footnotetext{
108 Mainville (n 19) 155-6, 163, 166, 176, 178.

109 Neil Brooks, 'The Judge and the Adversary System' in Allen M Linden and HW Arthurs (eds), The Canadian Judiciary (Osgoode Hall Law School, 1976) 93-4, 98-9.

110 David Kahane, 'What Is Culture? Generalizing about Aboriginal and Newcomer Perspectives' in Catherine Bell and David Kahane (eds), Intercultural Dispute Resolution in Aboriginal Contexts (UBC Press, 2004) 28, 31.

111 See Diana Lowe and Jonathan H Davidson, 'What's Old Is New Again: Aboriginal Dispute Resolution and the Civil Justice System' in Catherine Bell and David Kahane (eds), Intercultural Dispute Resolution in Aboriginal Contexts (UBC Press, 2004) 280, 280-1; Wenona Victor, 'Alternative Dispute Resolution (ADR) in Aboriginal Contexts: a Critical Review' (Research Paper, Canadian Human Rights Commission, April 2007) 5 <https://www.chrcccdp.gc.ca/sites/default/files/adrred_en_1.pdf>.

112 Kahane (n 110) 33.

113 Jeremy Webber, 'Commentary: Indigenous Dispute Settlement, Self-Governance, and the Second Generation of Indigenous Rights in Catherine Bell and David Kahane (eds), Intercultural Dispute Resolution in Aboriginal Contexts (UBC Press, 2004) 149, 151.

114 For discussions of hybrid systems developed by Indigenous peoples, see Dale Dewhurst, 'Parallel Justice Systems, or a Tale of Two Spiders' in Catherine Bell and David Kahane (eds), Intercultural Dispute Resolution in Aboriginal Contexts (UBC Press, 2004) 213; Catherine Bell ‘Indigenous Dispute Resolution Systems within Non-Indigenous Frameworks: Intercultural Dispute Resolution Initiatives in Canada' in Catherine Bell and David Kahane (eds), Intercultural Dispute Resolution in Aboriginal Contexts (UBC Press, 2004) 241.

115 Coyle, 'ADR Processes' (n 288) 392.
} 
through counsel and cross-examination is permitted and usual.116 At the same time, the Tribunal is authorized to establish special procedures, including Māori hearing protocols. ${ }^{117}$ For example, hearings may be held on the claimant's marae (meeting area), taking into account the procedures of the marae.118

Moreover, evidence may be given in te reo Māori (the Māori language) and the cross-examination of elders may be limited. ${ }^{119}$ While hybrid processes might offer advantages over strictly non-Indigenous processes, they do not overcome constitutional capture. When a hybrid process is built from incommensurable constitutional logics, one of those logics must serve as the medium through which differing constitutional norms are translated. ${ }^{120}$ Constitutional norms filtered through an incommensurable logic become distorted, producing constitutional capture. ${ }^{121}$

\section{Voice and Talking Circle Procedures}

The appeal to voice in contemporary scholarship is often grounded in a reaction against the formal equality of classical liberalism, according to which voice in the sense of one's lived experience is insignificant. All humans are equally entitled to the same set of rights given their shared human dignity. ${ }^{122}$ This principle is reflected in the procedures of the adversarial litigation process. Here, the only voices represented are those of the parties, which are attenuated through the filters of lawyers, legal doctrines, and the rules of evidence. Granted, as mentioned above, the adversarial process affords a certain amount of control to parties in the form of the right to choose how to frame their case and the proofs they present, as compared to an inquisitorial system where these functions are controlled by the judge. ${ }^{123}$ But these rights are grounded not in respect for voice in the sense of the lived experience of the parties, but rather in respect for their individual autonomy. ${ }^{124}$

In contrast, voice plays a prominent role within Anishinaabe dispute resolution procedures such as talking circles. Protocols for talking circles vary depending on the community and the purpose of the circle. ${ }^{125}$ The following are some common, but not necessarily universal, protocols which are used by some Anishinaabeg (as well as some other Indigenous communities). Talking circles can include a range of participants - not only those who would otherwise be in the positions of plaintiff and defendant-

116 Morris Te Whiti Love, 'The Waitangi Tribunal's Roles in the Dispute Resolution of Indigenous (Maori) Treaty Claims' in David J Kahane and Catherine Bell (eds), Intercultural Dispute Resolution in Aboriginal Contexts (UBC Press, 2004) $128,128,135,140$.

117 Ibid 140.

118 Coyle, 'Transcending Colonialism?' (n 299) 617.

119 Coyle, 'ADR Processes' (n 288) 397.

120 Mills, Miinigowiziwin (n 122) 28.

121 Ibid 28, 272. The adoption of ubuntu into South African law might be an instance of a successful hybrid, given the apparent overlap between some aspects of $u b u n t u$ and an Anishinaabe constitutional order: Marieke de Mooij, Human and Mediated Communication around the World: A Comprehensive Review and Analysis (Springer International Publishing, 2014) 141. But this system still seems prone to constitutional capture if the relationship between $u b u n t u$ and African law is analogous to that of equity and the common law, as TW Bennett suggests: TW Bennett, 'An African Doctrine of Equity in South African Public Law' (2011) 57(4) Loyola Law Review 709, 721. Equity is not a selfsufficient system; it presupposes the existence of the common law and thus is described as appendicular to the common law: AH Oosterhoff et al, Oosterhoff on Trusts: Text, Commentary and Materials (Thomson Canada, $6^{\text {th }}$ ed, 2004) 6. Treating Anishinaabe law as appendicular to the common law would do nothing to avert constitutional capture.

122 See Dale Turner, 'Perceiving the World Differently' in Catherine Bell and David Kahane (eds), Intercultural Dispute Resolution in Aboriginal Contexts (UBC Press, 2004) 57, 60-1.

123 Brooks (n 1099) 93-4.

124 Ibid 100.

125 For example, talking circles are used for decision-making, dispute resolution/healing, teaching, and sentencing. 
which creates space and time for the voices of all those potentially affected by the dispute to be heard. ${ }^{126}$ Family members, elders, and community members who can offer support are included in the circle. ${ }^{127}$ Everyone involved is seated in the circle, reflecting their equality; 128 no one is elevated (like a judge), nor segregated between the front and back of the room, nor separated by a bar (as in a court). An object is passed around the circle, often more than once. Each person has an opportunity to speak when it is their turn to hold the object, although no one is required to speak; the person holding the object is not interrupted (unlike objections in a court). ${ }^{129}$ Participants are encouraged to speak from the heart, 130 as opposed to through the filters of causes of action or defences. Further, 'what comes out in a circle, stays in a circle'. ${ }^{131}$ Participants can speak freely, knowing what they say in the circle will not be held against them going forward (in contrast to the open court principle). Together, these procedures facilitate relationship-building ${ }^{132}$ and encourage meaningful participation beyond lawyers and judges. ${ }^{133}$ No one person or sub-set of persons in the circle is entitled to determine the resolution of the dispute (as is a judge or jury). Everyone in the circle together is responsible for determining the root of the problem and how best to help those involved to heal. ${ }^{134}$ Each of these procedures giving effect to voice are grounded in the roots and trunk discussed in the previous section, including the radical interdependence of community members, the responsibility to communicate needs and gifts, the responsibility to share gifts, the operation of persuasive compliance through mutual aid, and the goal of restoring harmony through healing relationships. ${ }^{135}$

\section{A Non-Adjudicative Process}

To uphold Anishinaabe inaakonigewin and persuasive compliance, the proposed forum would be nonadjudicative. The facilitators would teach and model - but not impose-law. ${ }^{136}$ From a liberal perspective, the lack of a neutral adjudicator who issues binding decisions might seem to be a downfall. ${ }^{137}$ As Michael Coyle explains, independent assessments by bodies such as the Royal Commission on Aboriginal Peoples and the Ipperwash Inquiry raise concerns that settlements reached through unassisted negotiation will be unduly influenced by the significant imbalances in bargaining power between the parties rather than based on the merits of the claims. ${ }^{138}$ This is also a common critique of the duty to consult and accommodate pursuant to section 35. Although this duty is justiciable, its justiciability is severely limited by its being merely a procedural but not a substantive duty. ${ }^{139}$ It provides Aboriginal peoples with 'a

\footnotetext{
126 See Larry N Chartrand, 'Principles of Dene/Metis Dispute Resolution: Implications for the Sahtu Dene and Metis Land Claim Arbitration Panel' (Research Paper, Norman Wells: Arbitration Panel Meeting, 1996) 3.

127 R v Francis-Simms [2017] ONCJ 402, [14].

${ }_{128} R$ v Moses (1992) 71 CCC (3d) 347 [38], [49] ('Moses').

129 Deborah Simmons et al, 'Aboriginal talking circle: Aboriginal perspectives on caribou conservation' (2012) 32(2) Rangifer 17, 19.

130 See Lyn Trudeau and Lorenzo Cherubini, 'Speaking Our Truths in "A Good Way"' (2010) 33(1) Canadian Journal of Native Education 113, 113.

131 Moses (n 1288) 368. See also Lancaster (n 82) 343.

132 Simmons (n 1299) 18.

133 Moses (n 1288) 357.

134 Lancaster (n 82) 338, 340.

135 Ibid 340.

136 But see Ryan Beaton, 'Articles 27 and 46(2): UNDRIP Signposts Pointing beyond the Justifiable-infringement Morass of Section 35' in UNDRIP Implementation: More Reflections on the Braiding of International, Domestic and Indigenous Laws (Centre for International Governance Innovation, 2018) 111, 117.

137 Joanne Cave, 'From Rights Recognition to Reconciliation: Reflecting on the Government of Canada's Proposed Indigenous Rights Recognition Framework' (2019) 77 University of Toronto Faculty of Law Review 59, 71.

138 Coyle, 'Transcending Colonialism?' (n 299) 596, 601.

139 Haida Nation v British Columbia (Minister of Forests) [2004] 3 SCR 511, [42] ('Haida Nation').
} 
right to a process, not to a particular outcome'. ${ }^{140}$ The merely procedural nature is reflected in the proposition that the duty to consult and accommodate does not give Aboriginal peoples a veto. ${ }^{141}$ Indigenous peoples would be forgiven for rejecting a process that looks like another version of the duty to consult but with even less teeth.

Why would persuasive compliance be successful where the duty to consult and accommodate has failed? The answer is the duty to consult and accommodate is ensconced within liberalism, while persuasive compliance operates within Anishinaabe constitutionalism. As discussed above, persuasive compliance is effective when the parties have internalized the logic of mutual aid, including the radical interdependence of the parties. In contrast, the duty to consult and accommodate is informed by the principles of liberalism, according to which the parties are not only entitled to act solely in their own selfinterest to the extent permitted by law, but some parties are either legally required to do so (eg, corporations) or highly incentivized to do so (eg, governments seeking re-election). This is why the most significant function of the proposed forum is not to facilitate talking circles or other Indigenous dispute resolution procedures, but to provide the guidance needed to help Canadian government representatives internalize Indigenous constitutionalism. Persuasive compliance at the level of the branches only works when it is truly informed by the roots and the trunk.

\section{E No Party Would Have a Veto}

The proposed forum would not give an Anishinaabe nation a veto insofar as an Anishinaabe nation would not possess a right to unqualifiedly quash a proposed project. That being said, an Anishinaabe nation would be warranted in declining to consent to a proposed project within their territory for any reason that resonates within Anishinaabe constitutionalism (eg, if the project would prevent the nation from upholding their responsibilities including their responsibilities to the land, or if the federal and/or provincial government has not demonstrated a persuasive need for the project). But declining to give consent in this way is not a veto, as it would be open to Canadian governments to move a project to a different location or otherwise amend it to comply with our responsibilities within Anishinaabe constitutionalism. ${ }^{142}$ A veto is inconsistent with persuasive compliance. Thus, Canadian governments would no longer have a veto. Pursuant to existing doctrinal law, Canadian governments currently have a veto; they are legally entitled to approve projects unilaterally as long as they satisfy the procedural requirements of the duty to consult and accommodate in the case of unproven rights, or as long as they satisfy the requirements of the justification test in the case of established rights. ${ }^{143}$ A government who does this - who approves a project in violation of Anishinaabe constitutionalism - takes itself outside of the mutual aid relationship. Thus, no nation operating in accordance with Anishinaabe constitutionalism would have a veto.

\section{Conclusion}

Consistent with the meaning of inaakonigewin, I do not claim that this proposal is the only or even the best means of instantiating mutual aid, persuasive compliance, or deliberative law within a dispute resolution system. There may be many other ways of giving effect to these constitutional norms and procedures. What I have proposed is merely the best I am able to articulate at this time given my current experience

\footnotetext{
140 Ktunaxa Nation v British Columbia (Forests, Lands and Natural Resource Operations) [2017] 2 SCR 386, [83]. 141 Haida Nation (n 1399) [48].

142 See comments of Senator Murray Sinclair quoted in Justin Brake, '"Let us rise with more energy": Saganash responds to Senate death of C-262 as Liberals promise, again, to legislate UNDRIP', APTN National News (online, 24 June 2019) <https:/ / aptnnews.ca/2019/06/24/let-us-rise-with-more-energy-saganash-responds-to-senate-death-ofc-262-as-liberals-promise-again-to-legislate-undrip/>. 143 Beaton (n 1366) 115.
} 
and knowledge. ${ }^{144}$ And consistent with persuasive compliance, I am not making prescriptive claims. For those who want to understand how a dispute resolution procedure could be informed by Anishinaabe constitutionalism, this paper provides a suggestion. In other words, I offer not a directive to adopt Indigenous constitutionalism, but rather an invitation. ${ }^{145} \mathrm{I}$ hope you'll want to join us.

144 My current knowledge of Anishinaabe constitutionalism is limited in many ways, for example, by being mostly academic, which is only one limited form of knowledge within Anishinaabe epistemology: Mills, Miinigowiziwin (n 122) 131.

145 Ibid 151. 